\title{
THE INFLUENCE OF THE NUMBER OF LEAVES IN THE MACAÚBA PALM Acrocomia aculeata (Jacq.) Lodd. ex Mart. ON THE CORRELATION BETWEEN STEMFLOW AND GROSS PRECIPITATION ${ }^{1}$
}

\author{
João Batista Lúcio Corrêa ${ }^{2}$, Herly Carlos Teixeira Dias ${ }^{3 *}$, Aurora Yoshiko Sato ${ }^{4}$, Kelly Cristina Tonello ${ }^{5}$, \\ Alexandre Gomes Ferraz ${ }^{6}$ and Filipe Manoel Ferreira ${ }^{6}$
}

\footnotetext{
${ }^{1}$ Received on 21.08.2015 accepted for publication on 10.03.2016.

${ }^{2}$ Universidade Federal de Viçosa, Programa de Pós-Graduação em Ciências Florestais, Viçosa, MG, Brasil. E-mail: $<$ batistacefetrp@yahoo.com.br>.

${ }^{3}$ Universidade Federal de Viçosa, Centro de Ciências Agrárias, Departamento de Engenharia Florestal,Vicosa, MG - Brasil. E-mail: <herlycarlostdias@gmail.com>.

${ }^{4}$ Universidade Federal de Viçosa, Departamento de Biologia Vegetal, Laboratório de Anatomia Vegetal, Viçosa, MG, Brasil. E-mail: <aurorasato@gmail.com>.

${ }^{5}$ Universidade Federal de São Carlos, Departamento de Ciências Ambientais, Sorocaba, SP-Brasil. E-mail:<kellytonello@yahoo.com>. ${ }^{6}$ Universidade Federal de Viçosa, Graduando em Engenharia Florestal. Viçosa, MG - Brasil. E-mail: <alexandre.g.ferraz@ufv.br> and <filipe.manoel@ufv.br>.

*Corresponding author.
}

\begin{abstract}
The macaúba palm (Acrocomia aculeata) has a great production potential of oil and is an important alternative to diversify agricultural production. In view of the hypothesis that the species may provide a positive contribution to the hydrological processes in a watershed, we aimed to assess the influence of the number of leaves per macaúba plant on the correlation between stemflow and gross precipitation. We installed three rain gauges to monitor gross precipitation in an experimental area, and stemflow collectors on the stem of eight macaúba plants therein having 10, 13, 18, and 22 leaves. Linear regression equations were obtained, which enabled us to estimate the minimum rainfall volume required for the occurrence of stemflow. A strong positive linear correlation was observed between stemflow and gross precipitation, regardless of the number of leaves per plant. The morphological characteristics of the macaúba palm favor rainfall interception, relatively high stemflow values being shown even in young plants. The funnel-shaped crown enabled the conduction of large rainfall volumes to the stem, thus resulting in the occurrence of stemflow even with light precipitations.
\end{abstract}

Keywords: Forest hydrology; Rainfall interception; Infiltration.

\section{INFLUÊECIA DO NÚMERO DE FOLHAS DA PLANTA DE MACAÚBA Acrocomia aculeata (Jacq.) Lodd. ex Mart. NA CORRELAÇÃO ENTRE ESCOAMENTO PELO TRONCO E A PRECIPITAÇÃO EM ABERTO}

\begin{abstract}
RESUMO - Considerando o potencial produtivo da macaúba (Acrocomia aculeata), sua importância como alternativa na diversificação da produção agrícola, e tendo como hipótese uma positiva contribuição nos processos hidrológicos de uma bacia hidrográfica, este estudo teve por objetivo conhecer a influência do número de folhas da planta na correlação entre o escoamento pelo tronco (Et) e a precipitação em aberto (PA). Foram instalados três pluviômetros para o monitoramento da precipitação em aberto e coletores de escoamento pelo tronco no caule de oito plantas de macaúba com 10,13, 18 e 22 folhas. Foram obtidas equações de regressão que permitem estimar a partir de qual volume de chuva o escoamento pelo tronco se torna presente. Foi observada forte correlação linear positiva entre a precipitação em aberto (PA) e o escoamento pelo tronco (Et), independente do número de folhas por planta. A macaúba, por suas características morfológicas, favorece a captação da água de chuva, apresentando volume
\end{abstract}


relativamente elevado de escoamento pelo tronco (Et) em plantas ainda jovens. Pode-se, também, afirmar que sua copa em formato de funil conduz maior volume de água para o caule, iniciando o escoamento pelo tronco a partir de pequenos eventos de chuva.

Palavras-chave: Hidrologia florestal; Interceptação de chuva; Infiltração.

\section{INTRODUCTION}

The substitution of native vegetation for agricultural and forest crops leads to alterations in soil use. Although necessary for economic development, it favors the excessive erosion promoted by rainwaters. In this context, there is a growing concern for conciliating agricultural and forestry activities with greater soil protection, by employing management techniques and using cultures that enable rainwater to reach the soil with a lower impact, thus avoiding particle disaggregation, facilitating infiltration, and directing precipitation to water tables.

Stemflow is the rainwater that, after being intercepted by tree crowns, runs off through the branches and stems toward the soil. In order for stemflow to occur, the first event needed is crown saturation, i.e., the tree crown must reach its maximum capacity of water retention. After that, the stemflow process initiates (SHINZATO et al., 2011). According to Oliveira et al. (2011), despite being constantly neglected by several authors, as it represents a small portion of the annual hydric balance, stemflow has a great importance in the hydrological cycle, as it represents a volume of water that reaches the soil with low velocity, thus favoring infiltration and recharging water tables.

Besides rainfall features (intensity, duration, wind occurrence etc.), morphological characteristics of plant species presumably have a great influence on the percentage of rainwater that flows through the stem. Such percentage value may vary according to features like the tree basal area and diameter, and crown density and volume (ALVES et al., 2007).

Overall, palm trees have a well-defined crown shape, with the leaves distributed along the stipe. Presumably, the capacity for rainfall interception is strongly influenced by the number of leaves in the plant.

Dias et al. (2011) stated that the macaúba palm (Acrocomia aculeata (Jacq.) Lodd. ex Martius) has morphological characteristics that favor efficient water interception. The authors reported that the species crown shape resembles a funnel and that the species leaflets act as small gutters that direct the intercepted water to the leaf central portion. According to the authors, the species leaf sheaths, in turn, resemble larger gutters that direct the water to the stipe. The authors also stated that the presence of thorns and trichomes increases the interception surface, thus propitiating a high occurrence of stemflow.

The macaúba palm is native to tropical forests. In Brazil, the area of its occurrence extends from Pará to São Paulo, Rio de Janeiro, and Mato Grosso do Sul states, especially in areas of open vegetation, like the Cerrado and semideciduous and disturbed forests. The species has a simple stem, always cylindrical, rarely tumescent, with 20 to $30 \mathrm{~cm}$ in diameter, 10 to $15 \mathrm{~m}$ in height, and is covered by the persistent leaf bases (sheaths), which usually have thorns, especially in young plants (LORENZI et al., 2004).

The economic potential of the macaúba palm has encouraged the development of scientific research on its cultivation (DIAS et al., 2011). Several studies have indicated that the cultivated macaúba may reach the productivity of $4.8 \mathrm{t} / \mathrm{ha}$ of oil, an equivalent to the values obtained with the African oil palm. Currently, the African oil palm is the crop with the highest productivity of oil per cultivated ha, being also the species from which the largest amount of plant oil is produced worldwide. The advantage of macaúba over the African oil palm is its adaptability to the entire tropical zone in Latin America, while the cultivation of the latter is restricted to equatorial zones (PIMENTEL et al., 2011).

The macaúba palm therefore has a great production potential of oil and is an important alternative to diversify agricultural production. In view of the hypothesis that the species may provide a positive contribution to the hydrological processes in a watershed, we aimed to assess the influence of the number of leaves per macaúba plant on the correlation between stemflow and gross precipitation. This study has great relevance as it fills the gap on hydrological studies with the species, and as it will allow for the estimation of the stemflow volume in macaúba crops without the need for developing new experiments, by using the regression equations obtained. 


\section{MATERIALAND METHODS}

\subsection{Study area}

The study was conducted in the experimental farm of Federal University of Viçosa, in Araponga municipality, Minas Gerais state, Brazil. The farm is located between coordinates $20^{\circ} 40^{\prime} \mathrm{S}$ and $42^{\circ} 31^{\prime} \mathrm{W}$, at an $885 \mathrm{~m}$ altitude. According to Wagner Junior et al. (2013), based on Köppen's classification, the regional climate is type Cwb: subtropical/tropical altitude climate with dry winter and warm summer. Annual temperature ranges between 3 and $28^{\circ} \mathrm{C}$, and annual precipitation ranges from 1300 to $1500 \mathrm{~mm}$. The soil in the region is classified as dystrophic red-yellow latosol.

\subsection{Method}

One year-old saplings of macaúba palm (Acrocomia aculeata) were transplanted to a 1.7 ha area with a $5 \times 5 \mathrm{~m}$ spacing (680 plants) in February 2009. In the area, we monitored hydrological processes from September 2012 through August 2013. Rainfall was monitored using three rain gauges made of PVC pipes placed in the surroundings of the planted area. The gauge opening had $14.4 \mathrm{~cm}$ in diameter, which resulted in a total collection area of $162.86 \mathrm{~cm}^{2}$. Gauges were fixed so that their opening was placed at 1.50 $\mathrm{m}$ aboveground.

For stemflow measurement, gauges were installed in eight plants located in the plantation borders. The plants had their leaves counted on a monthly-basis from September 2012 through March 2013, the period with the heaviest rainfall, and according to their average number of leaves in the period, they were categorized in four classes: plants bearing 10, 13, 18, or 22 leaves (two plants in each class).

Prior to installing the collectors, stem thorns were removed. Collectors were made using motorcycle tires. For that, tires were cut in half, had all the rubber removed from the entire extension of one of the halves, and were fixed to the stems spirally. To eliminate crannies between the stem and the collector, we used silicone gel and polyurethane foam. Each collector was connected to two 25-L gallons by a 2" flexible hose.

Stemflow was obtained in L and converted to mm of water column. For that, we established: the collection area as the projection of the tree crown; and the leaf limit as the point after which the water moved toward the stipe. Stemflow was calculated by the equation:

$$
\mathrm{Sf}(\mathrm{mm})=\mathrm{V}(\mathrm{L}) / \mathrm{A}\left(\mathrm{m}^{2}\right)
$$

in which $\mathrm{Sf}=$ precipitation in millimeters $(\mathrm{mm})$; $\mathrm{V}=$ volume in liters $(\mathrm{L})$, and $\mathrm{A}=$ collection area in square meters $\left(\mathrm{m}^{2}\right)$.

\section{RESULTS}

Data was collected from 94 rainfall events from September 2012 through August 2013. Rainfall ranged between 2.83 and $55.65 \mathrm{~mm}$.

Gross precipitation totalized $1339.95 \mathrm{~mm}$, being a well representative value of local annual precipitation, which usually ranges from 1300 to $1500 \mathrm{~mm}$. The months with the heaviest, lightest, and absent rainfall were November 2012, August 2013, and July 2013, respectively (Table 1).

Stemflow value was 60.93 , which accounted for $4.55 \%$ of the total gross precipitation (Table 1 ).

For a same gross precipitation value, stemflow increased with increasing number of leaves in the macaúba plants. Stemflow values in plants with 10 , 13,18 , and 22 leaves were $36.45,56.79,78.94$, and 97.96 $\mathrm{mm}$, respectively. Thus, a 2.68-times increase in stemflow was observed in plants with 22 leaves in relation to those with 10 leaves (Table 2).

In August 2013 we registered the lowest gross precipitation $(3.21 \mathrm{~mm})$ and the highest stemflow, the latter showing a 5.3-times increase in plants with 22 leaves in relation to those with 10 leaves. The lowest such increase was verified in February 2013, which still was of a two-times magnitude (Table 2).

The highest frequency of rainfall events occurred with precipitations lower than $15 \mathrm{~mm}$, accounting for $65.5 \%$ of the total number of events. Thirty of such events occurred between the 5 and $10 \mathrm{~mm}$ range, and represented $34.5 \%$ of the total number of events. Only five events with precipitations higher than $40 \mathrm{~mm}$ were registered, averaging $48.73 \mathrm{~mm}$ (Table 3 ).

The average stemflow in the period, from a total 94 rainfall events, are shown in Figure 1. The stemflow values in plants with $10,13,18$, and 22 leaves accounted for $2.39,3.97,5.08$, and $6.72 \%$ of gross precipitation, respectively. The lowest stemflow percent occurred in plants with 10 leaves after rainfall events with

Revista Árvore, Viçosa-MG, v.40, n.3, p.387-393, 2016

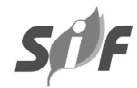


Table 1 - Monthly and annual values of gross precipitation (GP) and stemflow (Sf) in macaúba plants, in Araponga municipality, Minas Gerais state, Brazil. September 2012 through August 2013.

Tabela 1 - Valores mensais e anuais de precipitação em aberto (PA) e escoamento pelo tronco (Et) em plantas de Macaúba, Araponga, MG. Setembro de 2012 a agosto de 2013.

\begin{tabular}{lccc}
\hline \multicolumn{1}{c}{ Month } & GP $(\mathrm{mm})$ & $\mathrm{Sf}(\mathrm{mm})$ & $\mathrm{Sf}(\%$ of GP) \\
\hline September 2012 & 13.39 & 0.55 & 4.11 \\
October 2012 & 91.28 & 4.94 & 5.41 \\
November 2012 & 301.12 & 11.97 & 3.98 \\
December 2012 & 133.92 & 5.96 & 4.45 \\
January 2013 & 246.22 & 11.76 & 4.78 \\
February 2013 & 108.46 & 5.27 & 4.86 \\
March 2013 & 285.78 & 13.47 & 4.71 \\
April 2013 & 74.51 & 3.35 & 4.50 \\
May 2013 & 72.25 & 3.31 & 4.58 \\
June 2013 & 9.81 & 0.27 & 2.75 \\
July 2013 & 0.00 & 0.00 & 0.00 \\
August 2013 & 3.21 & 0.082 & 2.55 \\
\hline Total & 1339.95 & 60.93 & 4.55 \\
\hline
\end{tabular}

Table 2 - Monthly values of stemflow (Sf) in macaúba plants with different number of leaves, and monthly and annual values of gross precipitation (GP) in Araponga municipality, Minas Gerais state, Brazil. September 2012 through August 2013.

Tabela 2 - Valores mensais de escoamento pelo tronco (Et-mm) em plantas de macaúba com diferentes números de folhas, e valores mensais e anual de precipitação em aberto (PA-mm), Araponga, MG. Setembro de 2012 a agosto de 2013.

\begin{tabular}{|c|c|c|c|c|c|}
\hline Month & $\begin{array}{c}\mathrm{GP} \\
(\mathrm{mm})\end{array}$ & $\begin{array}{l}\text { Sf }(\mathrm{mm}) \\
10 \text { leaves }\end{array}$ & $\begin{array}{c}\text { Sf }(\mathrm{mm}) \\
13 \text { leaves }\end{array}$ & $\begin{array}{c}\text { Sf }(\mathrm{mm}) \\
18 \text { leaves }\end{array}$ & $\begin{array}{l}\mathrm{Sf}(\mathrm{mm}) \\
22 \text { leaves }\end{array}$ \\
\hline August 13 & 3.21 & 0.03 & 0.07 & 0.08 & 0.16 \\
\hline June 2013 & 9.81 & 0.18 & 0.22 & 0.33 & 0.41 \\
\hline September 2012 & 13.39 & 0.43 & 0.70 & 1.02 & 1.41 \\
\hline May 2013 & 72.25 & 1.90 & 2.28 & 4.13 & 5.16 \\
\hline April 2013 & 74.51 & 2.58 & 3.60 & 5.02 & 5.85 \\
\hline October 2012 & 91.28 & 2.67 & 3.83 & 6.01 & 7.83 \\
\hline February 2013 & 108.46 & 3.88 & 5.10 & 6.26 & 7.76 \\
\hline December 2012 & 133.92 & 3.04 & 5.47 & 7.42 & 9.65 \\
\hline January 2013 & 246.22 & 6.86 & 11.72 & 15.30 & 19.12 \\
\hline March 2013 & 285.78 & 9.09 & 11.47 & 16.90 & 21.56 \\
\hline November 2012 & 301.12 & 5.79 & 12.33 & 16.47 & 19.04 \\
\hline Total & 1339.95 & 36.45 & 56.79 & 78.94 & 97.96 \\
\hline
\end{tabular}

precipitation lower than $5.0 \mathrm{~mm}$, while the highest stemflow percent occurred in plants with 22 leaves after rainfall events with precipitation between 20 and $30 \mathrm{~mm}$.

The studied rainfall events enabled us to elaborate dispersion models for each plant category regarding the number of leaves, after which we could obtain the respective regression models. Figure 2 shows the dispersion, regression models, and coefficients of determination $\left(\mathrm{R}^{2}\right)$ of stemflow in plants with 10,13 , 18 , and 22 leaves.

\section{DISCUSSION}

There is a lack of studies stablishing the correlation between the external morphology of arboreal species and stemflow, especially in representatives of the Arecaceae family. Crown features of arboreal species have an influence on the interception and conduction of rainfall water. Thus, such features may either enhance or reduce stemflow. Lorenzon et al. (2015) evaluated the stemflow of arboreal individuals in an Atlantic Forest fragment in Viçosa municipality, Minas Gerais state, Brazil, between August 2009 and March 2011, and 
Table 3 - Average stemflow (Sf), expressed as percentage of gross precipitation (GP), in macaúba plants with different number of leaves, in Araponga municipality, Minas Gerais state, Brazil. September 2012 through August 2013.

Tabela 3 - Valores médios de escoamento pelo tronco (Et), expressos em percentual de precipitação em aberto (PA), em plantas de macaúba com diferentes números de folhas, município de Araponga, MG. Setembro de 2012 a agosto de 2013.

\begin{tabular}{|c|c|c|c|c|c|c|}
\hline Frequency & $\begin{array}{c}\mathrm{GP}(\mathrm{mm}) \\
\text { class }\end{array}$ & $\begin{array}{c}\text { GP } \\
(\mathrm{mm})\end{array}$ & $\begin{array}{c}\text { Sf } \\
(\% \text { of GP) } \\
10 \text { leaves }\end{array}$ & $\begin{array}{c}\text { Sf } \\
(\% \text { of GP) } \\
13 \text { leaves }\end{array}$ & $\begin{array}{c}\text { Sf } \\
(\% \text { of GP }) \\
18 \text { leaves }\end{array}$ & $\begin{array}{c}\text { Sf } \\
(\% \text { of GP) } \\
22 \text { leaves }\end{array}$ \\
\hline 14 & $<5.0$ & 3.85 & 1.06 & 1.72 & 2.19 & 3.37 \\
\hline 30 & $5.0-10.0$ & 7.13 & 2.17 & 3.21 & 4.49 & 5.02 \\
\hline 13 & $10.0-15.0$ & 12.46 & 2.51 & 3.98 & 5.5 & 6.95 \\
\hline 11 & $15.0-20.0$ & 17.66 & 2.56 & 4.44 & 6.48 & 8.53 \\
\hline 7 & $20.0-30.0$ & 24.97 & 3.48 & 5.43 & 7.41 & 9.16 \\
\hline 7 & $30.0-40.0$ & 35.38 & 2.94 & 4.65 & 6.92 & 9.00 \\
\hline 5 & $>40.0$ & 48.73 & 3.19 & 4.68 & 5.93 & 6.97 \\
\hline
\end{tabular}

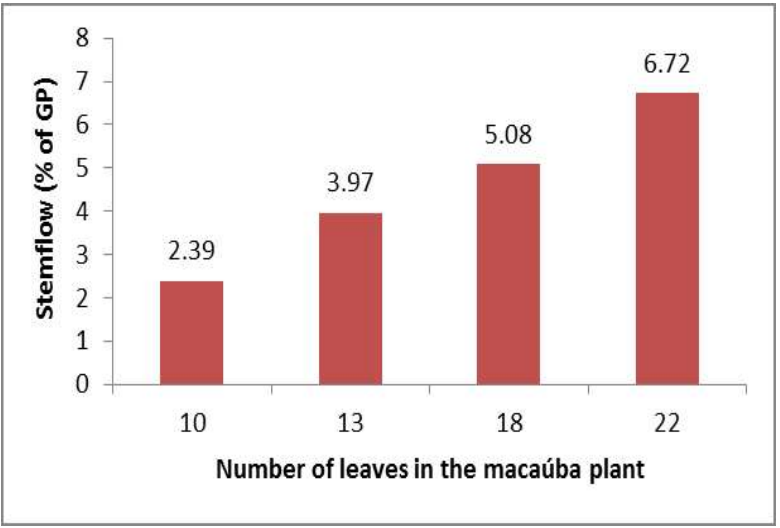

Figure 1 - Stemflow, expressed as percentage of gross precipitation (GP), in relation to the number of leaves in macaúba plants, in Araponga municipality, Minas Gerais state, Brazil. September 2012 through August 2013

Figura 1-Escoamento pelo tronco em percentagem de precipitação em aberto (PA), em relação ao número de folhas em plantas de macaúba, município de Araponga, MG. Setembro de 2012 a agosto de 2013.

observed that Euterpe edulis, also an Arecaceae representative, was the species that showed the highest stemflow values, which therefore indicates its importance for the conservation of water resources.

Arcova et al. (2003), in a study performed in a secondary Atlantic Forest region in São Paulo state, Brazil, where regenerative processes have been occurring for more than 45 years, observed a stemflow of $0.2 \%$ of gross precipitation. Oliveira Junior and Dias (2005), also working in a secondary Atlantic Forest area, in Viçosa municipality, Minas Gerais state, Brazil, reported a stemflow of $1.7 \%$ of gross precipitation. Oliveira et al. (2008), studying a dense forest region (500 trees/ ha) with an average canopy height of $35 \mathrm{~m}$ in the Amazon Forest, also observed a stemflow of $1.7 \%$ of gross precipitation. Thus, the stemflow value we found, of $4.55 \%$ of gross precipitation, in a macaúba plantation only 4.5 years old, may be considered high when compared with the values reported by these authors. The water the flows though tree stems reaches the soil with a lower impact, thus favoring its infiltration in the soil and the recharge of the water table.

The lowest stemflow percentage occurred after the lightest rainfall events. This is due to the fact that the plant canopy may be soaked first so that the stemflow can occur. However, regardless of the gross precipitation, we observed an increase in the stemflow percentages that was proportional to the number of leaves in the plants.

Based on the results shown in Table 3, we also observed that both the rainfall volume and the number of leaves in the plants have a directly proportional relationship with stemflow.

There was a strong positive linear correlation between gross precipitation and stemflow in all studied plants. In plants with 10 leaves the coefficient of determination $\left(\mathrm{R}^{2}\right)$ ranged around 0.80 , while in plants with 13,18 , and 22 leaves the $\mathrm{R}^{2}$ ranged around 0.88 (Figure 2). These results indicate that more than $80 \%$ of the stemflow values we registered can be explained by the variation in gross precipitation.

From the four regression equations obtained, we estimated that stemflow in macaúba occurs after gross precipitation equal to or greater than: $2.62 \mathrm{~mm}$ in plants with 10 leaves, $2.24 \mathrm{~mm}$ in plants with 13 leaves, 1.91

Revista Árvore, Viçosa-MG, v.40, n.3, p.387-393, 2016 

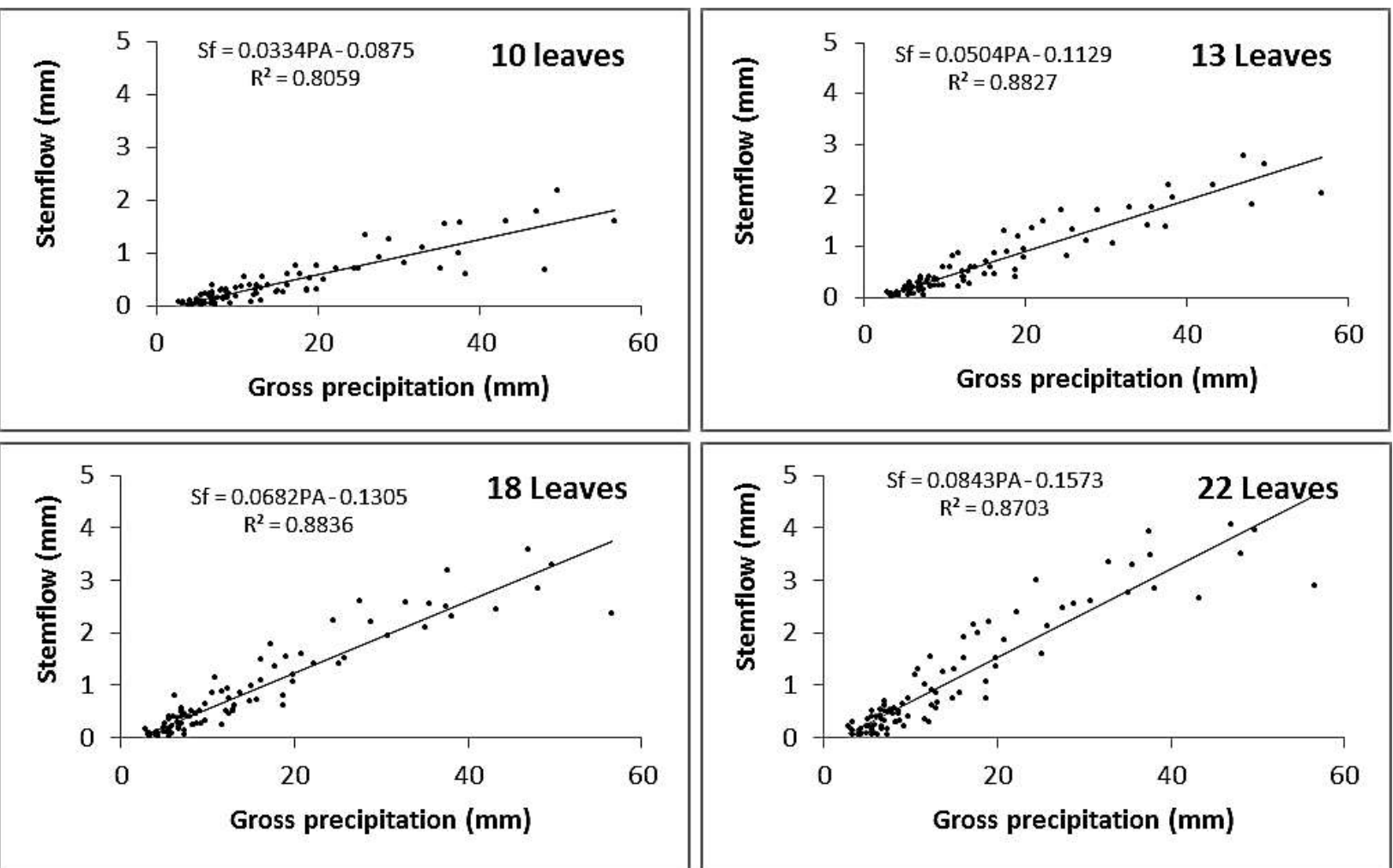

Figure 2 - Correlations between gross precipitation (GP) and stemflow ( $\mathrm{Sf}$ ) in macaúba plants with 10, 13, 18, and 22 leaves, in Araponga municipality, Minas Gerais state, Brazil. September 2012 through August 2013.

Figura 2 - Correlações entre precipitação em aberto (PA) e escoamento pelo tronco (Et) em plantas de macaúba com 10 folhas, 13 folhas, 18 folhas e 22 folhas, municipio de Araponga, MG. Setembro de 2012 a agosto de 2013.

$\mathrm{mm}$ in pants with 18 leaves, and 1.87 in plants with 22 leaves. According to Shinzato et al. (2011), stemflow only occurs after a gross precipitation equal to or greater than $11.0,6.6$, and $8.2 \mathrm{~mm}$ in a seasonal semideciduous forest, in Eucalyptus cloeziana, and in Pinus sp., respectively. Comparing our estimations with the values reported by these authors, we could conclude that the macaúba palm has a great capacity to intercept and direct rainfall waters to its stipe, thus allowing the occurrence of stemflow even with light rainfall events.

\section{CONCLUSION}

Due to its morphological characteristics, the macaúba palm (Acrocomia aculeata) favors rainfall interception, showing relatively high stemflow volumes even in young plants. The species funnel-shaped crown allows for the conduction of large rainfall volumes to its stem, thus resulting in the occurrence of stemflow even with light precipitations.

We observed a strong positive linear correlation between gross precipitation and stemflow, regardless of the number of leaves per plant. We conclude that the larger the number of leaves in a macaúba plant, the larger is its capacity for rainfall interception, and thus the lighter is the rainfall needed to initiate the stemflow process.

A high stemflow volume can be considered an advantageous feature, since water can then reach the soil with low kinetic energy, which favors its infiltration and minimizes erosive processes. In view of that, we also could infer that the macaúba palm has a great potential for being used in projects of recovery of degraded lands, as well as in the implementation of agroforestry systems aiming at the recovery of areas of permanent preservation. 


\section{REFERENCES}

ALVES, R.F.; DIAS, H.C.T.; OLIVEIRA JÚNIOR, J.C.; GARCIA, F.N.M. Avaliação da precipitação efetiva de um fragmento de Mata Atlântica em diferentes estágios de regeneração no município de Viçosa, MG. Revista Ambiente e Água, v.2, n.1, p.83-93, 2007.

ARCOVA, F.C.S.; CICCO, V.; ROCHA, P.A.B. Precipitação efetiva e interceptação das chuvas por floresta de Mata Atlântica em uma microbacia experimental em Cunha - São Paulo. Revista Árvore, v.27, n.2, p.257-262, 2003.

DIAS, H.C.T.; SATO, A.Y.; OLIVEIRA NETO, S.N.; MORAIS, T.C.; FREIRE, A.; BENTO, P.S. Cultivo de Macaúba: Ganhos ambientais em áreas de pastagens. Informe Agropecuário, v.32, p.52-60, 2011.

LORENZI, H.; SOUZA, H.M., MEDEIROS COSTA, J.T.; CERQUEIRA, L.S.C.; FERREIRA, E.

Palmeiras brasileiras e exóticas cultivadas. Nova Odessa: Instituto Plantarum, 2004. 432p.

LORENZON, A.S.; DIAS, H.C.T.; TONELLI, K.C. Escoamento da água da chuva pelo tronco das árvores em uma floresta estacional semidecidual. Revista Árvore, v.39, n.3, p.423-430, 2015.

OLIVEIRA, L.L.; COSTA, R.F.; SOUZA, F.A.S.; COSTA, A.C.L.; BRAGA, A.P. Precipitação efetiva e interceptação em Caxiuanã, na Amazônia Oriental. Acta Amazônica, v.38, n.4, p.723$732,2008$.

OLIVEIRA JUNIOR, J.C.; DIAS, H.C.T.

Precipitação efetiva em fragmento secundário de mata atlântica. Revista Árvore, v.29, n.1, p.9$15,2005$.

OLIVEIRA, L.L.; CUNHA, A.C.; COSTA, A.C.L.; COSTA, R.F. Sazonalidade e interceptação da chuva na Floresta Nacional em Caxiuanã Amazônia Oriental. Scientia Plena, v.7, n.10, p.1-14, 2011.

PIMENTEL, L.D.; MANFIO, C.E.; MOTOIKE, S.Y.; PAES, J.M.V.; BRUCKNER, C.H. Coeficientes técnicos e custos de produção do cultivo da macaúba. Informe Agropecuário, v.32, n.265, p.61-69, 2011 .

SHINZATO, E.T.; TONELLO, K.C.; GASPAROTO, E.A.G.; VALENTE, R.O.A. Escoamento pelo tronco em diferentes povoamentos florestais na Floresta Nacional de Ipanema em Iperó, Brasil. Scientia Forestalis, v.39, n.92, p.395-402, 2011.

WAGNER JUNIOR, A.; HORST BRUCKNER, C.; COSTA SILVA, J.O.; SANTOS, C.E.M.; PIMENTEL, L.D.; MAZARO, S.M. Chilling requirement for seed germination and phenological observations on peach cultivars. Revista Ceres, v.60, n.2, p.234-241, 2013. 